KS. ZBIGNIEW JANCZEWSKI

Wydział Prawa Kanonicznego

Uniwersytetu Kardynała Stefana Wyszyńskiego w Warszawie

\title{
UDZIELANIE KOMUNII ŚW. OSOBOM ROZWIEDZIONYM? ANALIZA ADHORTACJI AMORIS LAETITIA PAPIEŻA FRANCISZKA ${ }^{1}$
}

Treść: Wstęp. - 1. Eucharystia wyrazem jedności w Kościele i małżeństwie. - 2. Osoby żyjące w związkach cywilnych we wstrzemięźliwości seksualnej. - 3. Komunia św. osób rozwiedzionych w świetle Amoris laetitia. - Zakończenie.

\section{Wstęp}

Nierozerwalność małżeństwa wypływa z zamysłu samego Stwórcy. Co Bóg złączył, człowiek nie może rozdzielać, takie słowa w usta samego Jezusa wkładają święci ewangeliści Mateusz i Marek. Kto zaś zostawia swojego współmałżonka i bierze innego popełnia cudzołóstwo $^{2}$. Cudzołóstwo zawsze uważane było za grzech ciężki, a osoby tkwiące w takim grzechu nie mogą przystępować do sakramentalnej Komunii.

Rodziny żyjące we współczesnym świecie na początku XXI wieku borykają się z wieloma poważnymi problemami. Mówi się nawet o kryzysie rodziny, także katolickiej. Skutkiem tego procesu są coraz częściej rozpadające się małżeństwa, nawet takie, które łączy związek sakramentalny. Jakiś czas po rozpadzie, niektórzy małżonkowie

\footnotetext{
${ }^{1}$ Referat wygłoszony na konferencji Ordynariatu Wojska Polskiego odbywającej się w dniach 8-9 czerwca 2016 r. w Gnieźnie.

${ }^{2}$ Mt 19, 6; Mk 10, 9; Mt 19,19.
} 
próbują zaradzić swojej sytuacji szukając rozwiązania w nowym związku, legalizowanym przez zawarcie tzw. małżeństwa cywilnego, lub żyjąc poza legalnym związkiem. Wraz z wyrzutami sumienia, pojawia się u niektórych $\mathrm{z}$ nich potrzeba przystępowania do Komunii Eucharystycznej, której wcześniej się pozbawili.

Niniejsze opracowanie jest próbą odpowiedzi na pytanie, czy wspomniane osoby całkowicie utraciły już prawo do przyjęcia sakramentalnego Ciała Chrystusa, w świetle obowiązujących dokumentów Stolicy Apostolskiej, a szczególnie wydanej ostatnio adhortacji papieża Franciszka Amoris laetitia. W pierwszej części ukazana zostanie Eucharystia jako wyraz jedności we wspólnocie Kościoła oraz w małżeństwie. Druga część dotyczy możliwości przystępowania do Komunii św. przez osoby pozostające w związkach cywilnych i prowadzące ze sobą życie jak brat i siostra. Ostatnia część to analiza wspomnianej powyżej papieskiej adhortacji, w interesującym nas aspekcie.

\section{Eucharystia wyrazem jedności w Kościele i małżeństwie}

Przystępowanie do Komunii św. jest wyrazem jedności przyjmujących ją osób. To twierdzenie odnosi się zarówno do wspólnoty Kościoła, jak i wspólnoty małżeństwa. Trudno jest jednak mówić o jedności rodziny związanej sakramentalnym węzłem małżeńskim w przypadku, gdyby było możliwe jego rozwiązanie. Stąd też Bóg ustanawiając małżeństwo uczynił je nierozerwalnym³ ${ }^{3}$. Kościół w swoim nauczaniu zawsze odwoływał się do słów Jezusa o nierozerwalności małżeństwa, więź wewnętrzna łącząca małżonków została ustanowiona przez Stwórcę i nie podlega ludzkim regulacjom ${ }^{4}$.

Doktryna Kościoła o nierozerwalności małżeństwa została ogłoszona na Soborze Florenckim w roku 1439. Nierozerwalność węzła małżeńskiego jest znakiem nierozerwalnego zjednoczenia Chrystusa

\footnotetext{
${ }^{3}$ Mt 5, 32 .

${ }^{4}$ U. Navarette, La giurisdizione delle Chiese orientali non cattoliche sul matrimonio (can. 780 C.C.C.O.), w: Il matrimonio nel Codice dei Canoni delle Chiese Orientali, Studi Giuridici XXXII, Citta del Vaticano 1994, s. 112.
} 
z Kościołem ${ }^{5}$. Nauczanie to zostało następnie potwierdzone na Soborze Trydenckim ${ }^{6}$. W Kodeksie prawa kanonicznego z 1917 roku nierozerwalność małżeństwa wymieniana jest jako istotny jego przymiot, z racji sakramentalności takiego związku. Stąd nie można go rozwiązać ludzką władzą ${ }^{7}$. Deklarują to również obowiązujące kodeksy - łaciński z 1983 roku $^{8}$ i katolickich Kościołów wschodnich $\mathrm{z}$ roku $1990^{9}$.

Wszyscy ochrzczeni są powołani do pełnego wszczepienia we wspólnotę eucharystyczną, przez co Eucharystia oznacza i urzeczywistnia jedność Kościoła. Duch św. jednoczy wierzących, tworząc $\mathrm{z}$ nich jedno ciało ${ }^{10}$. Domaga się również od jej uczestników pełnego włączenia w ciało eklezjalne oraz pełnej komunii z Chrystusem i innymi członkami Wspólnoty. Eucharystia ofiarowana podczas Mszy św. Bogu Ojcu i dana Kościołowi jako pożywienie, jest znakiem jedności takiej Wspólnoty w miłości. Ponadto zmierza do tego, aby ochrzczeni doszli do pełnego zjednoczenia z Bogiem i ludźmi, urzeczywistnianego właśnie w Ciele i Krwi Chrystusa ${ }^{11}$.

W małżeństwie i rodzinie, nazywanej „domowym Kościołem” dojrzewa pierwsze eklezjalne doświadczenie komunii między osobami, w której dzięki łasce odzwierciedla się tajemnica Trójcy św. ${ }^{12}$ Wzajemny dar konstytutywny dla sakramentalnego małżeństwa ma swoje zakorzenienie w łasce chrztu, który ustanawia fundamentalne przymierze każdej osoby z Chrystusem w Kościele. Chrystus przez sakramentalne przymierze małżonków pozostaje z nimi, dając moc pójścia za nim, podnoszenia się po upadkach, przebaczania sobie

\footnotetext{
${ }^{5}$ Bulla unionis Armenorum Exultate Deo, 22.11.1439, w: Dokumenty Soborów Powszechnych, opr. A. Baron, H. Pietras, t. 3, Kraków 2004, s. 525.

${ }^{6}$ Sess.XXIV, Canones de sacramento matrimonii, can. 5, w: Dokumenty Soborów Powszechnych, opr. A. Baron, H. Pietras, t. 4/2, Kraków 2004, s. 714-715.

${ }^{7}$ Kan. 1013 par. 2; kan. 1118.

${ }^{8}$ Kan. 1056, 1141.

${ }^{9}$ Kan. 776, 853.

${ }^{10}$ B. Testa, Sakramenty Kościoła, Poznań 1998, s. 183.

11 Tamże, s. 184.

${ }^{12}$ Katechizm Kościoła Katolickiego, nr 1657, Poznań 1994.
} 
wzajemnie, wzajemnego noszenia swoich ciężarów. Małżeństwo chrześcijańskie uobecnia miłość Chrystusa w komunii małżonków. Poprzez złączenie ich w jedno ciało reprezentuje ono zaślubiny Syna Bożego z ludzką naturą ${ }^{13}$.

Skoro Eucharystia jest wyrazem i uobecnieniem jedności osób ją przyjmujących z Jezusem Chrystusem oraz innymi członkami Kościoła, nie powinni ją przyjmować grzesznicy, którzy popełniając grzech ciężki (zwany również śmiertelnym), znaleźli się niejako na marginesie takiej jedności ${ }^{14}$. Dotyczy to także osób, które w swoim życiu rozstały się ze współmałżonkiem i lekceważąc fakt nierozerwalności zawartego sakramentalnego małżeństwa, weszły w nowe związki z innym partnerem, tworząc następną rodzinę. $Z$ drugiej jednak strony, jak pisze w posynodalnej adhortacji Amoris letitia z dnia 19 marca 2016 roku papież Franciszek, przez długi czas Kościół kładąc nacisk na kwestie doktrynalne bioetyczne i moralne, niedostatecznie wspierał rodziny, umacniając więź małżonków, wypełniając sensem ich wspólne życie. Niezwykle trudno jest bowiem zaprezentować małżeństwo jako dynamiczny proces rozwoju i realizacji, a łatwiej jako ciężar, jaki należy wspólnie znosić przez całe życie. Z trudem też znajdowało się miejsce dla sumienia wiernych, którzy często pośród różnorakich swoich ograniczeń, odpowiadają najlepiej jak potrafią na Ewangelię, mogąc rozwijać własne rozeznanie w sytuacji, kiedy wszystkie systemy upadają. Kościół jest powołany do kształtowania sumień, a nie ich zastępowania ${ }^{15}$. Papież Franciszek w swoim dokumencie nie idzie (co jest zrozumiałe), drogą zmiany doktryny, dotyczącej nierozerwalności małżeństwa sakramentalnego, ale podejmuje się próby nowej, bardziej złożonej oceny moralnej postępowania osób żyjących poza swoim związkiem sakramentalnym, związanych teraz

\footnotetext{
${ }^{13}$ Franciszek, Posynodalna Adhortacja Apostolska Amoris Laetitia, O miłości w rodzinie, nr 73, Kraków 2016; W dalszej części używam skrótu: AL.

${ }^{14}$ Z. JAnCZEwski, Przyjmowanie Eucharystii przez osoby żyjące w małżeństwach niesakramentalnych, w: Reddite ergo qua sunt caesaris caesari et qua sunt Dei Deo. Studia in honorem prof. Josephi Krukowski dedicata, Lublin 2015, s. 398.

${ }^{15}$ AL nr 37.
} 
z nowym partnerem, z którym tworzą następną rodzinę, w kontekście ich uczestnictwa w Eucharystii.

\section{Osoby żyjące w związkach cywilnych we wstrzemięźliwości seksualnej}

Papież Franciszek w adhortacji Amoris laetitia stwierdza, że należy pomóc każdemu w znalezieniu jego sposobu uczestnictwa we wspólnocie kościelnej, aby czuł się przedmiotem Bożego miłosierdzia. Nikt nie może zostać potępiony na zawsze, bo taka nie jest logika Ewangelii. Jeżeli jakieś osoby afiszują się obiektywnym grzechem tak, jakby były częścią chrześcijańskiego ideału, albo próbują narzucić styl swojego postępowania innym, muszą na nowo usłyszeć Ewangelię i wezwanie do nawrócenia. Należy podejść duszpastersko do żyjących jedynie w małżeństwach cywilnych, rozwiedzionych, którzy żyją w nowych związkach, lub tych, którzy jedynie razem mieszkają i ukazać im Bożą pedagogikę łaski i pomóc w osiągnięciu z mocą Ducha św. pełni planu Boga ${ }^{16}$.

Jaka jest sytuacja wymienionych osób w odniesieniu do przyjmowania Eucharystii? W adhortacji apostolskiej Sacramentum caritatis z 22 lutego 2007 r. poprzednik papieża Franciszka - Benedykt XVI pisał: nie dopuszcza się do sakramentów osób rozwiedzionych, które zawarły nowe związki, ponieważ swoim stanem i sytuacją życiową obiektywnie sprzeciwiają się jedności i miłości pomiędzy Chrystusem i Kościołem, która jest oznaczona i realizowana w Eucharystii ${ }^{17}$. To samo oczywiście dotyczy innego rodzaju związków (np. konkubinatów), żyjących poza sakramentalnym małżeństwem.

Kościół dopuszcza jednak wyjątki. Są one w pewnym sensie owocem i skutkiem refleksji licznych synodów diecezjalnych i polemik naukowych, które miały miejsce po Soborze Watykańskim $\mathrm{II}^{18}$.

\footnotetext{
${ }^{16}$ Tamże, nr 297.

${ }^{17}$ Benedy K XVI, Posynodalna adhortacji apostolska Sacramentum caritatis, nr 29, Katowice 2007.

${ }^{18}$ H. Muller, Barmherzigkeit in der Rechtordung der Kirche?, Archiv fur katholisches Kirchenrecht 159(1990) s. 353-367; E. Szczot, Dopuszczenie do Komunii
} 
Interesujące nas kwestie reguluje adhortacja apostolska Familiaris consortio Jana Pawła II z 22 listopada 1981 roku. W dokumencie czytamy, iż Kościół postanowił określić sytuacje i warunki umożliwienia przystępowania do sakramentu pokuty i Eucharystii pewnej grupie rodzin, które zagubione i niepewne wobec powierzonych sobie zadań, niemal zatraciły świadomość znaczenia oraz prawdy życia małżeńskiego i rodzinnego ${ }^{19}$. Jedyną istniejącą drogą do przyjęcia Komunii św. jest uzyskanie sakramentalnego rozgrzeszenia, udzielanego osobom żałującym naruszenia znaku przymierza i wierności Chrystusowi i gotowym na podjęcie takiej formy życia, która nie stoi w sprzeczności z nierozerwalnością małżeństwa. A zatem dotyczy to mężczyzny i kobiety, którzy z ważnych powodów, na przykład dla wychowania dzieci, mogą uczynić zadość zobowiązaniu separacji, postanawiając żyć w pełnej wstrzemięźliwości i powstrzymać się od aktów przysługujących jedynie małżonkom ${ }^{20}$.

Problematykę tę podjęła również 24 czerwca 2000 roku Papieska Rada ds. Tekstów Prawnych w deklaracji na temat zakazu przyjmowania Komunii św. przez osoby rozwiedzione, żyjące w nowych związkach cywilnych. Nawiązując do normy zawartej w kan. 915 Kodeksu prawa kanonicznego, zakazującej dopuszczania do Eucharystii osób z uporem trwających w jawnym grzechu ciężkim, stwierdza, że wspomniane osoby nie znajdują się w stanie notorycznego grzechu ciężkiego, jeżeli postanawiają żyć w pełnej wstrzemięźliwości, czyli powstrzymują się od aktów przysługujących jedynie małżonkom oraz na podstawie złożonego oświadczenia otrzymali rozgrzeszenie sakramentalne. Jednakże, ponieważ fakt, że wspomniane osoby nie żyją w grzechu ciężkim jest ukryty, podczas gdy ich sytuacja pozostawania w związku cywilnym stanowi fakt publiczny, mogą oni przyjmować

św. wiernego katolika podlegajacego normie kann. 915 KPK, Roczniki Nauk Prawnych 8(1998) z. 2, s. 210.

${ }^{19}$ Jan PAWE€ II, Adhortacja apostolska Familiaris consortio, nr 1, w: AAS 74(1982), s. 181.

${ }^{20}$ Tamże, nr 84. 
Eucharystię jedynie remoto scandalo ${ }^{21}$. Takie osoby zachęca się, aby zobowiązały się do przeżywania swojego związku według wymogów prawa Bożego, jak brat i siostra, natomiast duszpasterze w każdym przypadku powinni unikać błogosławienia takich związków, aby to nie powodowało wśród wiernych zamieszania w odniesieniu do wartości sakramentalnego małżeństwa ${ }^{22}$.

Kościół zatem dopuszcza do Komunii św. osoby żyjące w związkach cywilnych, po wcześniejszym zawarciu sakramentalnego małżeństwa $z$ inną osobą, jeżeli uznając naukę o nierozerwalności małżeństwa i żałują za swoją niewierność, której się dopuścili przez odejście od współmałżonka. Z drugiej strony jednak nie mają możliwości pozostawienia swojego obecnego partnera, z którym pozostają w związku cywilnym, ze względu na wychowywane wspólnie dzieci, albo świadczenie sobie wzajemnej opieki. Muszą jednak na zawsze zobowiązać się do zachowywania wstrzemięźliwości seksualnej w obecnym związku oraz do unikania wywoływania zgorszenia wśród osób, które nie znają ich zobowiązań i mogą domniemywać, że żyjąc w związku cywilnym przystępują do Komunii św. Takiego zgorszenia można zazwyczaj uniknąć przystępując do sakramentów pokuty i Eucharystii poza własną parafiąa ${ }^{23}$.

Do niedawna prawo do wyrażania zgody na przystępowanie powyższych osób do wspomnianych sakramentów posiadali ich ordynariusze miejsca, określając równocześnie warunki, na jakich osoby decydujące się na wspólne pożycie we wstrzemięźliwości mogły przyjmować sakramenty. Obowiązujące obecnie prawo nie utrzymuje takich wyłącznych kompetencji ordynariuszy. Osoby żyjące wspólnie zobowiązane są jedynie do szczerej gotowości na taką formę życia, która nie pozostaje w sprzeczności z nierozerwalnością małżeństwa, a więc jeżeli zgodnie z kan. 960 nie zachodzi wątpliwoś, co

\footnotetext{
${ }^{21}$ Pontificio Consiglio per L'interpretazione Dei Testi Legislativi, Dichiarazione The Code, w: Enchiridion Vaticanum, t. 19, s. 521.

${ }^{22}$ Benedykt XVI, dz. cyt., nr 29.

${ }^{23}$ Z. JANCZEWSKI, dz. cyt., s. 404-405.
} 
do dyspozycji penitentów proszących o rozgrzeszenie, spowiednik powinien go udzielić ${ }^{24}$.

Osoby rozwiedzione żyjące w nowych związkach powinny odczuwać, że w dalszym ciągu są częścią Kościoła, tworząc jego wspólnotę. Ich sytuacja wymaga uważnego rozeznania i towarzyszenia im z wielkim szacunkiem oraz popierania udziału w życiu tej wspólnoty. Troska o takich wiernych nie jest dla Kościoła osłabieniem jego wiary i świadectwa o nierozerwalności małżeństwa, ponieważ w takiej trosce wyraża on swoją miłość ${ }^{25}$.

Reasumując powyższe rozważania należy podkreślić, że posoborowe rozstrzygnięcia Stolicy Apostolskiej w interesującej nas kwestii poszły w kierunku indywidualnej oceny moralnej postępowania konkretnej osoby żyjącej poza sakramentalnym małżeństwem. Jej zachowanie (chodzi o powstrzymanie się od współżycia seksualnego), po poddaniu ocenie przez spowiednika, pozwala na przyjmowanie Komunii św.

\section{Komunia św. osób rozwiedzionych w świetle Amoris laetitia}

Powszechna dyskusja dotycząca dopuszczania osób rozwiedzionych, żyjących w nowych związkach, do przyjmowania Eucharystii toczy się w Kościele od dawna. Została również podjęta na Synodzie Biskupów w 2015 roku. Prefekt Kongregacji Nauki Wiary abp. Gerhard Ludwig Muller dwa lata wcześniej, na łamach watykańskiego L'Osservatore Romano z dnia 23 października 2013 r. pisał, że tendencja odwoływania się jedynie do Bożego miłosierdzia przy dopuszczaniu wspomnianych do Komunii św. byłaby traktowaniem miłosierdzia na zasadzie swego rodzaju remedium, dostosowanego do sytuacji i potrzeb. Można przy tym popaść w niebezpieczeństwo banalizacji samego wizerunku Boga, zgodnie z którym, Bóg nie mógłby postępować inaczej, jak tylko przebaczać. Owszem, jest On miłosierny, ale do Jego tajemnicy należą również świętość i sprawiedliwość. Jeżeli przesłania się te atrybuty i nie traktuje poważnie

\footnotetext{
${ }^{24}$ E. Szczot, dz. cyt., s. 217.

${ }^{25}$ AL nr 243.
} 
rzeczywistości grzechu, nie można przekazywać osobom Jego miłosierdzia $^{26}$. Jak słusznie zauważa cytowany autor, Pan Bóg nie okazuje swojego miłosierdzia zupełnie bezwarunkowo każdemu grzesznikowi, wymagając najpierw nawrócenia i skruchy.

Dnia 19 marca 2016 roku ukazała się posynodalna adhortacja papieża Franciszka Amoris laetitia. Stanowi ona zwieńczenie i zarazem podsumowanie wcześniejszych obrad Synodu Biskupów poświęconego małżeństwu i rodzinie. Dokument, jak zauważa Ojciec św., nabiera szczególnego sensu w kontekście obchodzonego właśnie Jubileuszowego Roku Miłosierdzia, stanowiąc propozycję dla chrześcijańskich rodzin, pobudzającą do docenienia darów małżeństwa i rodziny oraz do podtrzymania ich miłości ${ }^{27}$. Porusza również trudne problemy miejsca rodzin rozbitych w Kościelnej komunii.

W obliczu skomplikowanej sytuacji rodzin poranionych, duszpasterze dla miłości i prawdy, mają obowiązek właściwego jej rozeznania. Stopień odpowiedzialności małżonków za rozpad ich związku nie jest równy w każdym przypadku i mogą wystąpić czynniki ograniczające zdolność podejmowania przez nich decyzji ${ }^{28}$. W tym kontekście warto przywołać słowa wygłoszone w dniu 15 lutego 2016 r. przez papieża Franciszka do nowo mianowanych kardynałów - w całych dziejach Kościoła spotykają się dwie logiki: usuwania na margines i włączania do Wspólnoty. Od Soboru Jerozolimskiego drogą Kościoła stała się droga Chrystusa, czyli miłosierdzia i integracji, niepotępiania nikogo na wieczność, ofiarowanie miłosierdzia Bożego wszystkim ludziom o nie proszącym. Albowiem prawdziwa miłość jest zawsze bezwarunkowa, bezinteresowna i niezasłużona ${ }^{29}$.

Osoby rozwiedzione, żyjące w nowym związku, mogą się znaleźć w bardzo odmiennych sytuacjach, które nie powinny być zbyt

\footnotetext{
${ }^{26}$ G. I. Muller, Inissolubilita del matrimonio e dibattito sui divorziati riposato e i sacramento. La forza della grazia, L'Oservatore Romano, 23.10.2013, s. 4-5; Tekst polski: http://www.vatican.va/roman curia/congregations/cfaih/muller/rc con cfaih 20131023 divorziati-riposati-sacramenti pl.html [dostęp: 20.05.2016].

${ }^{27}$ AL nr 5.

${ }^{28}$ Tamże, nr 79.

${ }^{29}$ AAS 107(215), s. 257.
} 
surowo oceniane. Przykładowo, czym innym jest drugi związek, który z upływem czasu się umocnił, związek z nowymi dziećmi, sprawdzoną wiernością, poświęceniem, chrześcijańskim zaangażowaniem, świadomością nieprawidłowości swojej sytuacji oraz wielką trudnością, aby cofnąć się wstecz bez popadnięcia w nowe winy ${ }^{30}$. Kościół, jak nauczał Jan Paweł II w adhortacji Familiaris consortio, uznaje sytuacje, kiedy mężczyzna i kobieta dla ważnych powodów, na przykład wychowania dzieci, nie mogą uczynić zadość obowiązkowi rozstania się ${ }^{31}$.

Inny przypadek ma miejsce, kiedy osoba podjęła wielki wysiłek ratowania swojego pierwszego małżeństwa, doznając niesprawiedliwego porzucenia. Ponadto zdarza się, że zawiera się nowy związek ze względu na wychowanie dzieci będąc w sumieniu subiektywnie pewnym, że wcześniejsze małżeństwo, nieodwracalnie zniszczone, nie zostało ważnie zawarte ${ }^{32}$.

Biorąc pod uwagę niezwykłą złożoność takich i podobnych sytuacji Synod Biskupów zajmując się problemami rodziny nie zdecydował się na stworzenie nowych norm ogólnych typu kanonicznego, które by regulowały postępowanie we wszystkich przypadkach. Adhortacja Amoris laetitia zachęca jednak do odpowiedzialnego rozeznania osobistego oraz duszpasterskiego każdego indywidualnego przypadku ${ }^{33}$. W Kościele nastąpiło zatem niejako wycofanie problemu z płaszczyzny kanonicznej na czysto sakramentalną, opartą o nauczanie teologii moralnej i praktykę penitencjarną.

Jak zauważał już wcześniej, podczas dyskusji naukowej odbywającej się przed wspominanym Synodem Biskupów autor niniejszego opracowania, problem niedopuszczania do tej pory (za wyjątkiem przypadków opisanych we wcześniejszym punkcie) rozwiedzionych po zawarciu kontraktu cywilnego z inną osobą do Eucharystii, wiązał się z ciągłym pozostawaniem przez nich w grzechu cudzołóstwa,

\footnotetext{
${ }^{30}$ AL nr 298.

${ }^{31}$ Jan Pawe€ II, Adhort. apost. Familiaris consortio, dz.cyt., s. 186.

${ }^{32}$ Tamże.

${ }^{33}$ AL nr 300.
} 
uznawanego za grzech ciężki. Jednak do popełnienia tego rodzaju grzechu nie wystarcza jedynie ciężka jego materia, z którą w takim przypadku mamy niewątpliwie do czynienia. Potrzebna jest równocześnie świadomość i dobrowolność takiego postępowania. Jawi się zatem niezwykle istotne pytanie. Czy osoby posiadające Boże powołanie do życia w małżeństwie i rodzinie (ze wszystkimi tego konsekwencjami) oraz praktykujące wcześniej takie życie w małżeństwie sakramentalnym, rzeczywiście są w stanie po rozpadzie związku sakramentalnego żyć już zawsze w celibacie - bezżeństwie i wstrzemięźliwości seksualnej, wbrew wspomnianemu powołaniu otrzymanemu od Stwórcy. Jeżeli tak nie jest, czy uprawnione jest mówienie o pełnej dobrowolności popełnianego przez nich grzechu? ${ }^{34}$

Podobnym tokiem rozumowania poszła omawiana adhortacja papieska. Zadaniem kapłanów jest towarzyszenie zainteresowanym osobom na drodze rozeznania, rozmowa na forum wewnętrznym, przyczynia się do stworzenia prawidłowej oceny tego, co utrudnia możliwość pełniejszego uczestnictwa w życiu Kościoła ${ }^{35}$. Papież Franciszek zaznacza, że „nie można już mówić, że wszyscy, którzy znajdują się w sytuacji tak zwanej nieregularnej, żyją w stanie grzechu śmiertelnego, pozbawieni łaski uświęcającej”. Osoba znająca dobrze normę moralną może mieć duże trudności w zrozumieniu zawartych w niej wartości, albo też znaleźć się w określonych warunkach niepozwalających działać inaczej i podejmować inne decyzje bez zaciągania nowej winy. Tak więc mogą zaistnieć czynniki ograniczające zdolność podejmowania decyzji przez interesujące nas osoby ${ }^{36}$.

W Katechizmie Kościoła Katolickiego czytamy, że „Poczytalność i odpowiedzialność za działanie mogą zostać zmniejszone, a nawet zniesione, na skutek niewiedzy, nieuwagi, przymusu, strachu, przyzwyczajeń, nieopanowanych uczuć oraz innych czynników psychicznych lub społecznych" ${ }^{37}$. W myśl tego dokumentu odpowiedzialność

\footnotetext{
${ }^{34}$ Z. JANCZEWski, dz. cyt., s. 410.

${ }^{35}$ AL nr 300.

36 Tamże, nr 301.

${ }^{37}$ Katechizm Kościoła Katolickiego..., nr 1735.
} 
zmniejszają również niedojrzałość uczuciowa, nabyte nawyki, stany lękowe i inne czynniki psychiczne oraz społeczne ${ }^{38}$. Stąd w pewnych okolicznościach ludzie napotykają na poważne trudności, aby postępować inaczej, niż czynili to dotychczas. Zatem rozeznanie duszpasterskie, które uwzględnia prawidłowo uformowane sumienie, musi czuć się odpowiedzialne za tego rodzaju sytuacje. Podobnie skutki popełnionych czynów, nie muszą zawsze być takie same ${ }^{39}$. Biorąc pod uwagę konkretne uwarunkowania, powinno się lepiej włączyć ludzkie sumienie do praktyki Kościoła w niektórych sytuacjach, obiektywnie odbiegających od katolickiego rozumienia małżeństwa. Sumienie może uznać nie tylko to, że konkretna sytuacja obiektywnie nie odpowiada ogólnym postanowieniom Ewangelii. Może jednakże również szczerze i uczciwie uznać, że to, co w danej chwili jest wielkoduszną odpowiedzią, jaką można dać Bogu, odkrywając z jakąś pewnością moralną, że jest to dar wymagany od samego Boga, pośród złożoności ograniczeń, pomimo że nie jest to w pełni obiektywny ideał. Takie rozeznawanie jest procesem dynamicznym, pozwalając z czasem na zrealizowanie ideału w pełniejszy sposób ${ }^{40}$.

Biorąc pod uwagę powyższe, ze względu na uwarunkowania i czynniki łagodzące, możliwe jest, że pośród pewnej obiektywnej sytuacji grzechu, osoba, która nie jest subiektywnie albo w pełni winna, może żyć w łasce Bożej, kochać, wzrastać w życiu łaski i miłości, otrzymując w tym celu pomoc Kościoła. Eucharystia nie jest nagrodą dla doskonałych, ale szlachetnym lekarstwem dla słabych ${ }^{41}$.

Cytowane dokumenty papieskie zdają się więc uznawać, że niektóre osoby żyjące poza sakramentalnym związkiem małżeńskim nie popełniają grzechu ciężkiego ze względu na różne okoliczności łagodzące czy też czynniki niejako zmuszające je do takiego sposobu życia. Skoro w takich przypadkach nie występuje przesłanka

\footnotetext{
${ }^{38}$ Tamże, nr 2352.

${ }^{39}$ AL nr 302.

40 Tamże, nr 303.

${ }^{41}$ Franciszek, Adhort. Apost. Evangelii gaudium, 24.11.2013, nr 47, AAS 105(2013), s. 1039; AL nr 305.
} 
dobrowolności popełnianego grzechu, konieczna aby uznać go za ciężki, spowiednik, zgodnie z wielowiekową praktyką i nauczaniem doktrynalnym Kościoła, ma prawo udzielić rozgrzeszenia, a przez to dopuścić do przyjęcia Eucharystii.

Papież w analizowanej przez nas adhortacji wyraźnie jednak zaznacza, że aby uniknąć wszelkich błędnych interpretacji, trzeba pamiętać, że Kościół w żadnym przypadku nie może wyrzec się proponowania pełnego ideału małżeństwa, Bożego planu w całej swojej okazałości. Zrozumienie sytuacji wyjątkowych nigdy nie oznacza ukrywania światła pełniejszego ideału ani proponowania mniej, niż to, co Jezus ofiaruje Człowiekowi. Dzisiaj bardziej istotny niż duszpasterstwo niepowodzeń staje się duszpasterski wysiłek na rzecz umacniania małżeństw i zapobiegania ich rozpadom ${ }^{42}$.

Czy w świetle powyżej przytoczonych słów papieskich można powiedzieć, że Franciszek zmienił doktrynę Kościoła na temat małżeństwa i jego nierozerwalności? Taka teza jest absolutnie nieuzasadniona. Doktryna ta nie została zmieniona i nie może być inna w przyszłości. Małżeństwo, jako sakrament nierozerwalny pozostaje takowym z woli samego Boga. Kościół nie ma tu więc żadnych możliwości dokonywania zmian.

Bardziej zasadnym pozostaje inne pytanie. Czy zmieniło się spojrzenie Kościoła na możliwość przyjmowania Komunii św. przez osoby rozwiedzione? Dyscyplina Kościoła katolickiego zawsze ewaluowała i tak będzie również w przyszłości. Jeszcze na początku poprzedniego stulecia jakikolwiek, najmniejszy grzech dotykający 6 przykazania Bożego był uznawany za śmiertelny, a osoby żyjące jak brat z siostrą w związku cywilnym po rozpadzie małżeństwa sakramentalnego, nie posiadały żadnego prawa do przyjęcia Komunii św. W drugiej połowie XX w. to się zmieniło, co zostało pokazane w drugiej części tego opracowania. Papież Franciszek w swojej adhortacji, będącej podsumowaniem obrad Synodu Biskupów zdaje się iść o kolejny krok naprzód. Dotyka kwestii dyscyplinarnych, a konkretnie sposobu oceny moralnej postępowania interesujących nas osób.

${ }^{42}$ AL nr 307. 
Jakie zatem powinno być teraz działanie duszpasterzy w odniesieniu do osób rozwiedzionych, pragnących przystąpić do sakramentu pokuty i Eucharystii? Wydaje się, że problem jest zbyt istotny dla Kościoła i samych zainteresowanych, aby można było zdając się jedynie na odpowiedzialność spowiedników rozpocząć praktykę rozgrzeszania wspomnianych. Stolica Apostolska, powinna jednak wydać instrukcję, wskazującą na sposób postępowania duszpasterzy. „Liberalne” traktowanie kwestii spowiedzi i Komunii św. rozwiedzionych może bowiem jeszcze bardziej przyczynić się do pro rozwodowego podejścia niektórych osób do małżeństwa. Należałoby ustanowić pewne prawne ograniczenia i procedury postępowania, do których można by zaliczyć:

a) konieczność wcześniejszego rozpatrzenia przez sąd kościelny kwestii, czy rozbite małżeństwo było w ogóle ważne z punktu widzenia prawa kanonicznego, ponieważ wierni na pierwszym miejscu mają obowiązek życia w małżeństwie sakramentalnym i może istnieć szansa na zawarcie drugiego związku jako sakramentalnego,

b) przystępowanie do sakramentów należy ograniczyć jedynie do osób po zawarciu związku cywilnego, a nie żyjących w konkubinacie, potwierdzających niejako aktem cywilnym wzajemną miłość, chęć bycia ze sobą na stałe, troskę o nową rodzinę i uznania innych konsekwencji wypływających z podlegania w kwestii małżeństwa prawu cywilnemu,

c) przyjęcie zobowiązania, że osoby proszące o sakramenty będą się starać regularnie i przykładnie wypełniać obowiązki katolika wobec Boga i bliźnich ${ }^{43}$.

Zarówno obrady Synodu Biskupów na temat małżeństwa i rodziny, jak i posynodalna adhortacja apostolska budziły i budzą nadal wiele kontrowersji wśród wiernych, w tym również i naukowców. Można się spotkać ze stwierdzeniami, że Boże miłosierdzie jest dostępne zawsze i dla wszystkich, ale równocześnie nie ma ono możliwości działania tam, gdzie nie ma woli poprawy. Dlatego dyskusja o Eucharystii dla

${ }^{43}$ Z. JANCZEWSKI, dz. cyt., s. 410. 
rozwiedzionych powinna iść jedynie w kierunku uświadamiania im niezmienności prawa Bożego, aby nie pozwolić na poczucie zepchnięcia na margines Kościoła ${ }^{44}$. Jak pokazało życie, dyskusja, a szczególnie rozważania papieskie poszły również $\mathrm{w}$ alternatywnym (o ile tak można powiedzieć) kierunku.

A zatem, jak pisze O’Connell, Ojciec Święty rozpoczął proces, który daje nadzieję wielu ludziom i który w perspektywie czasu może odnowić oblicze Kościoła ${ }^{45}$.

\section{Zakończenie}

Niniejsze opracowanie stanowi próbę odpowiedzi na pytanie, czy osoby rozwiedzione, żyjące w nowych, niesakramentalnych związkach, całkowicie utraciły prawo do przyjęcia sakramentalnego Ciała Chrystusa, w świetle obowiązujących dokumentów Stolicy Apostolskiej, a szczególnie wydanej ostatnio adhortacji papieża Franciszka Amoris laetitia.

Kościół w swoim nauczaniu zawsze odwoływał się do słów Jezusa o nierozerwalności małżeństwa, więź wewnętrzna łącząca małżonków została ustanowiona przez Stwórcę i nie podlega ludzkim regulacjom. W małżeństwie i rodzinie, nazywanej „domowym Kościołem” dojrzewa pierwsze eklezjalne doświadczenie komunii między osobami. Małżeństwo chrześcijańskie uobecnia miłość Chrystusa w komunii małżonków. Poprzez złączenie ich w jedno ciało reprezentuje ono zaślubiny Syna Bożego z ludzką naturą. Skoro Eucharystia jest wyrazem i uobecnieniem jedności osób ją przyjmujących z Jezusem Chrystusem oraz innymi członkami Kościoła, nie powinni ją przyjmować grzesznicy, którzy popełniając grzech ciężki, znaleźli się niejako na marginesie takiej jedności. Dotyczy to także osób, które

\footnotetext{
${ }^{44}$ U. NowickA, Komunia dla rozwodników? Refleksja na kanwie wypowiedzi Prefekta Kongregacji Nauki Wiary z 23.10.2013 r., w: Reddite ergo qua sunt caesaris caesari et qua sunt Dei Deo. Studia in honorem prof. Josephi Krukowski dedicata, Lublin 2015, s. 544-546.

${ }^{45}$ G. O'Connell, Dlatego adhortacja daje nadzieję wielu ludziom, http:// www.m.deon.pl/religia/kosciol-i-swiat/komentarze/art,2417,dlatego-adhortacja-daje-nadzieje-wielu-ludziom.html, [dostęp 29.05.2016].
} 
w swoim życiu rozstały się ze współmałżonkiem i lekceważąc niejako fakt nierozerwalności zawartego sakramentalnego małżeństwa, weszły w nowe związki z innym partnerem, tworząc następną rodzinę.

Papież Franciszek w swojej najnowszej adhortacji Amoris laetitia stwierdza, że należy pomóc każdemu w znalezieniu jego sposobu uczestnictwa we wspólnocie kościelnej, aby czuł się przedmiotem Bożego miłosierdzia. Jego poprzednik Benedykt XVI pisał, że nie dopuszcza się do sakramentów osób rozwiedzionych, które zawarły nowe związki, ponieważ swoim stanem i sytuacją życiową obiektywnie sprzeciwiają się jedności i miłości pomiędzy Chrystusem i Kościołem, która jest oznaczona i realizowana w Eucharystii. To jednak zgodnie z deklaracją Papieskiej Komisji Interpretacji Tekstów Prawnych uznaje się, iż nie znajdują się w stanie notorycznego grzechu ciężkiego osoby, które postanawiają żyć w pełnej wstrzemięźliwości, czyli powstrzymują się od aktów przysługujących jedynie małżonkom oraz na podstawie złożonego oświadczenia otrzymały rozgrzeszenia sakramentalne. Jednakże, ponieważ fakt, że wspomniane osoby nie żyją w grzechu ciężkim jest ukryty, podczas gdy ich sytuacja pozostawania w związku cywilnym stanowi fakt publiczny, mogą przyjmować Eucharystię jedynie remoto scandalo.

Posynodalna adhortacja Amoris laetitia stanowi zwieńczenie i zarazem podsumowanie wcześniejszych obrad Synodu Biskupów poświęconego małżeństwu i rodzinie. Dokument, jak zauważa Ojciec św., nabiera szczególnego sensu w kontekście obchodzonego właśnie Jubileuszowego Roku Miłosierdzia, stając się dla chrześcijańskich rodzin propozycją pobudzającą do docenienia darów małżeństwa i rodziny oraz do podtrzymania ich miłości. Porusza również trudne problemy miejsca rodzin rozbitych w Kościelnej komunii.

W obliczu skomplikowanej sytuacji rodzin poranionych, duszpasterze dla miłości i prawdy mają obowiązek właściwego jej rozeznania. Stopień odpowiedzialności małżonków za rozpad ich małżeństwa nie jest równy w każdym przypadku i mogą wystąpić czynniki ograniczające zdolność podejmowania przez nich decyzji. Osoby rozwiedzione, żyjące w nowym związku, mogą się znaleźć w bardzo odmiennych sytuacjach, które nie powinny być zbyt surowo oceniane. Czym innym 
jest drugi związek, który z upływem czasu się umocnił, z nowymi dziećmi, sprawdzoną wiernością, poświęceniem, chrześcijańskim zaangażowaniem, świadomością nieprawidłowości swojej sytuacji oraz wielką trudnością, aby cofnąć się wstecz bez popadnięcia w nowe winy, niż powstały przypadkowo, dla zaspokojenia własnego egoizmu. Papież Franciszek zaznacza, że „nie można już mówić, że wszyscy, którzy znajdują się w sytuacji tak zwanej nieregularnej, żyją w stanie grzechu śmiertelnego, pozbawieni łaski uświęcającej”. Ponadto osoba znająca dobrze normę moralną może mieć duże trudności w zrozumieniu zawartych w niej wartości, albo też znaleźć się w określonych warunkach niepozwalających działać inaczej i podejmować inne decyzje bez zaciągania nowej winy. Tak więc mogą zaistnieć czynniki ograniczające zdolność podejmowania decyzji przez interesujące nas osoby. Ze względu na uwarunkowania i czynniki łagodzące, możliwe jest, że pośród pewnej obiektywnej sytuacji grzechu osoba, która nie jest subiektywnie, albo w pełni winna, może żyć w łasce Bożej, kochać, wzrastać w życiu łaski i miłości, otrzymując w tym celu pomoc Kościoła. Eucharystia nie jest nagrodą dla doskonałych, ale szlachetnym lekarstwem dla słabych.

Cytowane dokumenty papieskie zdają się zatem uznawać, że niektóre osoby żyjące poza sakramentalnymi małżeństwami nie popełniają grzechu ciężkiego ze względu na różne okoliczności łagodzące, czy też czynniki niejako zmuszające je do takiego sposobu życia. Skoro w takich przypadkach nie występuje konieczna przesłanka dobrowolności popełnianego grzechu, aby uznać go za ciężki, spowiednik, zgodnie z wielowiekową praktyką i nauczaniem doktrynalnym Kościoła, ma prawo udzielić rozgrzeszenia, a przez to dopuścić do przyjęcia Eucharystii. Wydaje się jednak, że problem jest zbyt istotny dla Kościoła i samych zainteresowanych, aby można było zdając się jedynie na odpowiedzialność spowiedników rozpocząć praktykę rozgrzeszania wspomnianych. Stolica Apostolska, powinna wydać instrukcję, wskazującą na sposób postępowania duszpasterzy. Zbyt „liberalne” traktowanie kwestii spowiedzi i Komunii św. rozwiedzionych może bowiem jeszcze bardziej przyczynić się do pro rozwodowego podejścia niektórych osób do małżeństwa. Należałoby 
więc ustanowić pewne prawne ograniczenia i adekwatne procedury postępowania.

\section{Communication of the blessed Eucharist to divorced persons? Analysis popes Francis adoration "Amoris laetitia"}

Many catholic peoples after divorce can receive the blessed Eucharist. New popes document "Amoris laetitia" details relative to that question. This elaboration in the first part shows Eucharist as expression of unity in the Church and marriage. Next part is about receiving Body of Christ by persons leaves in not sexual relations in the civil marriage. The last part is about Holly communion divorced persons on the scope of "Amoris laetitia". This document not changes Doctrina of the Church in those matter. Pope Francis try changes only discipline of Roman Catholic Church.

SŁOWA KLUCzowe: Komunia św., spowiedź, rozwód, małżeństwo cywilne, dyscyplina Kościoła rzymsko katolickiego.

KEYwORDS: blessed Eucharist, penance, divorce, civil marriage, discipline of Roman Catholic Church.

Nota o Autorze:

Ks. PROF. ZW. DR HAB. ZbignieW JANCZeWSKI - pracownik naukowo-dydaktyczny na Wydziale Prawa Kanonicznego Uniwersytetu Kardynała Stefana Wyszyńskiego w Warszawie, kierownik Katedry Prawa o Posłudze Uświęcania. 